Article

\title{
Screening Antibody Libraries with Colony Assay Using scFv-Alkaline Phosphatase Fusion Proteins
}

\author{
Yoshiro Hanyu 1,*(D) and Mieko Kato ${ }^{2}$ \\ 1 Biomaterials Research Group, Health and Medical Research Institute, National Institute of Advanced \\ Industrial Science and Technology (AIST), 1-1-1 Higashi, Tsukuba 305-8566, Japan \\ 2 Department of Biochemistry, Bio-Peak Co., Ltd., 584-70 Shimonojo, Takasaki 370-0854, Japan; \\ mieko.kato@bio-peak.com \\ * Correspondence: y.hanyu@aist.go.jp; Tel.: +81-298-61-5542
}

Academic Editor: Diego Muñoz-Torrero

Received: 26 May 2020; Accepted: 21 June 2020; Published: 24 June 2020

\begin{abstract}
Screening antibody libraries is an important step in establishing recombinant monoclonal antibodies. The colony assay can identify positive clones without almost any false-positives; however, its antibody library is smaller than those used in other recombinant screening methods such as phage display. Thus, to improve the efficiency of colony assays, it is necessary to increase library size per screening. Here, we report developing a colony assay with single-chain variable fragment (scFv) fused to the N-terminus of bacterial alkaline phosphatase (scFv-PhoA). The scFv-PhoA library was constructed in an expression vector specifically designed for this study. Use of this library allowed the successful and direct detection of positive clones exhibiting PhoA activity, without the need for a secondary antibody. Colony assay screening with scFv-PhoA is simple, rapid, offers a higher success rate than previous methods based on scFv libraries, and-most importantly-it enables high-throughput procedures.
\end{abstract}

Keywords: antibody; single-chain Fv (scFv); alkaline phosphatase; Escherichia coli; screening; colony assay

\section{Introduction}

Monoclonal antibodies are indispensable for research, diagnostic, and therapeutic purposes [1,2]. To meet the demand, methods capable of rapidly generating monoclonal antibodies with high affinity and specificity are required. Furthermore, there is a need for functional antibodies with antagonistic and agonistic properties towards the target protein. To obtain antibodies with various binding characteristics, one needs to establish a large number of clones owing to the generally low percentage of positive ones. The hybridoma method is widely used for the establishment of monoclonal antibodies; however, its screening procedure is time- and labor-consuming. Moreover, the small size of the library results in an insufficient number of positive clones. In comparison, recombinant technology is more advantageous as it relies on the use of large libraries [3-5]. In phage display, antibodies are displayed on phages in the form of single-chain variable fragment ( $\mathrm{scFv}$ ) libraries, and the clones with antigen affinity are selected by bio-panning [6-8]. However, this screening method suffers from elevated rates of false-positive clones [9-11].

Colony assays for screening scFv libraries have been developed [12,13]. The scFv library is expressed in Escherichia coli bacteria, which are grown on a hydrophilic filter placed on an antigen-coated membrane. Colonies form on the filter, scFv antibodies produced by the colonies diffuse out, they bind to the antigen on the membrane, and their presence is detected by superimposing the spot on the colony. A gene encoding scFv with affinity for the antigen is obtained. The colony assay identifies clones with high reliability by directly observing antibody-antigen binding, thus resulting in a low false-positive rate. In addition, the method can be easily used to screen libraries with an order of 
magnitude larger $\left(10^{5} \sim 10^{6}\right)$ than those employed in hybridoma technology $\left(10^{3} \sim 10^{4}\right)$, resulting in more positive clones over a shorter period. Nevertheless, the size of a colony assay library is much smaller than that afforded by phage display $\left(10^{9} \sim 10^{10}\right)$ [3]. To obtain monoclonal antibodies with the desired characteristics, the colony assay needs to be sufficiently efficient to handle larger libraries.

Here, we aimed to improve colony assay efficiency by replacing $\mathrm{scFv}$ with $\mathrm{scFv}$ fused to bacterial alkaline phosphatase (scFv-PhoA). The strategy of Pho-A fusion was successfully applied to produce in E.coli various eukaryotic molecules, including hormones [14,15] and antibody fragments [16-20]. All these fusion proteins were secreted in periplasm of E. coli where they folded correctly, yielding homogeneous, stable, and bifunctional molecules. Fusion of scFv to the $\mathrm{N}$-terminus of bacterial alkaline phosphatase considerably improved performance [21,22]. The periplasmic localization of PhoA-tagged scFv ensures dimerization of the PhoA moiety into its enzymatically active form and the correct folding of $\mathrm{scFv}$ via disulfide bond formation [23]. PhoA enables direct enzymatic detection of scFv fusions without the need for a secondary reagent such as an anti-His-tag antibody [24]. Positive clones showing specific binding to the antigen could be detected directly and rapidly, thus strongly improving assay processivity.

\section{Results}

\subsection{Development of the Colony Assay with scFv-PhoA}

The colony assay procedure based on the scFv-PhoA library is illustrated in Figure 1. The hydrophilic filter and antigen-coated nitrocellulose membrane were placed on the agar plate, and bacteria transformed with the scFv-PhoA library were spread on the filter. Colonies became visible after $14 \mathrm{~h}$ of incubation at $30^{\circ} \mathrm{C}$, at which point, scFv-PhoA expression was autoinduced. The bacterial colonies produced soluble periplasmic scFv-PhoA fusions, and those showing affinity against the antigen were captured by the antigen immobilized on the membrane. After incubation for $24 \mathrm{~h}$ at $30^{\circ} \mathrm{C}$, the filter harboring the colonies was transferred to a fresh agar plate and the nitrocellulose membrane was developed to detect antigen-binding scFv-PhoA fusions by chemiluminescence. This was achieved simply by applying the alkaline phosphatase substrate without using additional enzyme-conjugated antibodies and corresponding washing and reaction steps, thus shortening protocol time to about $1 / 10$ of the original. To identify positive colonies, the filter and the membrane were superimposed so that the colonies on the filter and the positive chemiluminescence signals were aligned. The colonies corresponding to the positive signals were then picked and cultured in the medium to identify candidate genes.

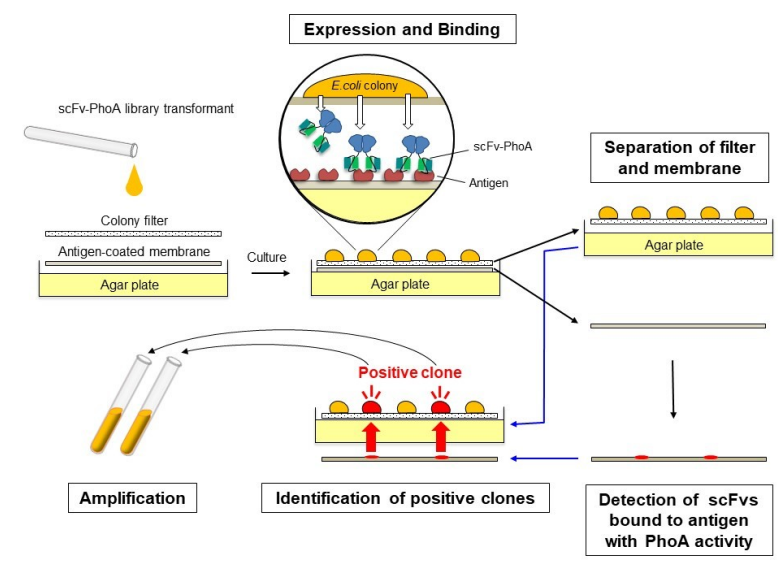

Figure 1. Schematic diagram of the procedure describing the colony assay with a single-chain variable fragment fused to the $\mathrm{N}$-terminus of bacterial alkaline phosphatase (scFv-PhoA). ScFv-PhoA fusions are expressed and secreted from E. coli. Those with the desired affinity bind the antigen beneath the colonies and are detected directly after applying the alkaline phosphatase substrate. Positive clones are identified as the colonies matching the positive signals on the membrane. 


\subsection{Construction of the Expression VECTOR for Screening}

A schematic diagram of the DNA construct used for screening is shown in Figure 2 together with its restriction sites. The vector pET-NXNN-PhoA was designed and constructed based on pET-NXNN [25], which we built previously for a colony assay using scFvs and was based on pET22b (+) (Merck Millipore, Darmstadt, Germany). To allow the systematic secretion of ScFv-PhoA into the periplasmic space, we replaced the signal peptide pelB of pET-NXNN with the intact signal peptide of PhoA (ssPhoA) by NdeI and NcoI. Then, we inserted a mutated version of the bacterial alkaline phosphatase gene (phoA) [26] after the cloning site for scFvs by NotI and Bpu1102I. To ensure systematic processing of the PhoA signal peptide, the cloning site for $\mathrm{scFv}$ was located between codons +6 and +7 of the phoA gene [23].

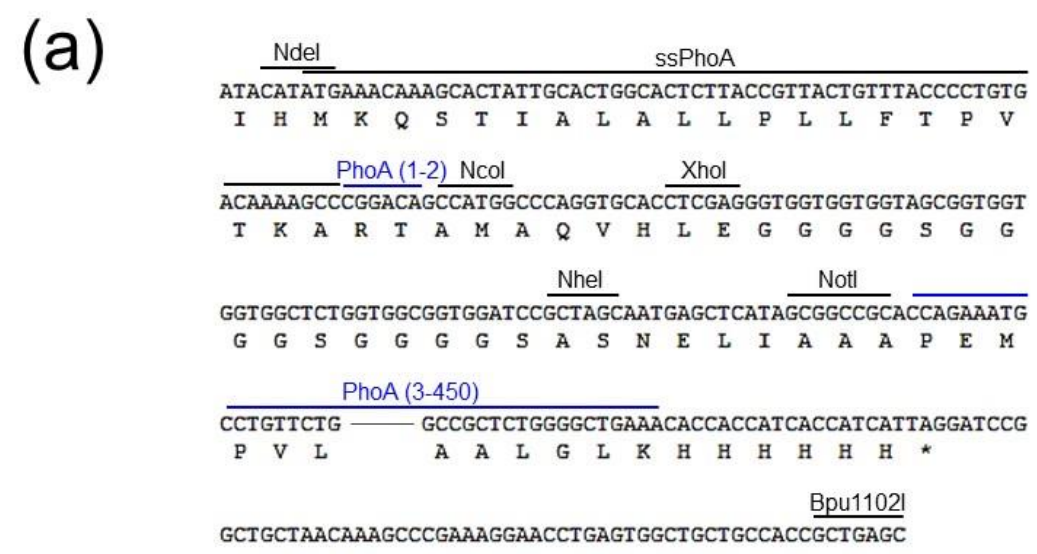

(b)

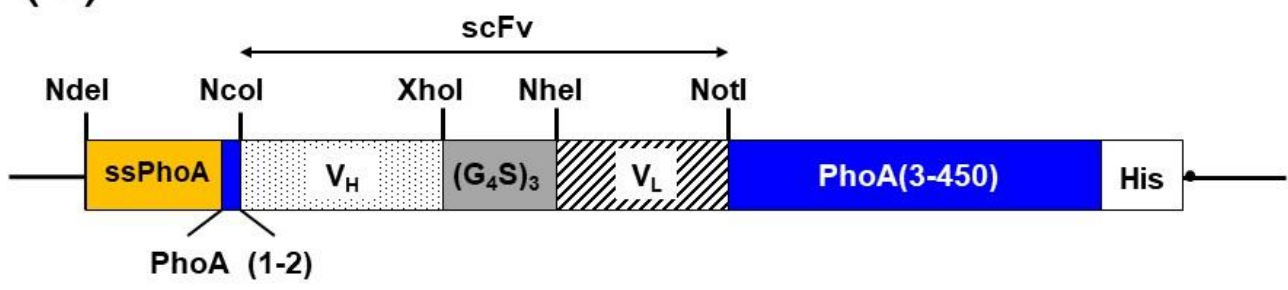

Figure 2. (a) Partial sequence of pET-NXNN-PhoA shown together with the cloning site and the restriction sites used in the cloning strategy. (b) Schematic representation of scFv cloned into pET-NXNN-PhoA. Orange square, signal sequence for PhoA (ssPhoA); blue square, two N-terminal amino acids of PhoA (PhoA (1-2)); dotted rectangle, heavy-chain variable domain $\left(\mathrm{V}_{\mathrm{H}}\right)$; gray square, linker $\left(\left(\mathrm{G}_{4} \mathrm{~S}\right)_{3}\right)$; striped rectangle, light-chain variable domain $\left(\mathrm{V}_{\mathrm{L}}\right)$; blue rectangle, PhoA (3-450); white square, His-tag; black circle, stop codon.

\subsection{Screening the scFv-PhoA Library}

The colony assay with the scFv-PhoA library was tested by selecting positive clones from an immune scFv library using human IgG as the antigen (Figure 3). E. coli were transformed with the scFv library and $3 \times 10^{3}$ cells in a solution containing glucose and lactose were spread on a hydrophilic polyvinylidene difluoride (PVDF) filter placed on top of an antigen-coated nitrocellulose membrane on a $10 \mathrm{~cm}$ agar plate. Following incubation for $14 \mathrm{~h}$ at $30^{\circ} \mathrm{C}$, colonies with a diameter of 0.6-0.9 mm were observed. Antigen binding of scFvs to the lower membrane was detected directly by chemiluminescence in a procedure that took only $10 \mathrm{~min}$ per membrane, compared to the $2 \mathrm{~h}$ for scFvs. Avoiding secondary antibodies allowed us to reduce not only time but also background, as indicated by a higher signal-to-noise ratio of the spots compared to that of the scFv library. This, in turn, allowed the use of a lower concentration of lactose as inducer and potentially avoided the growth inhibition caused 
by elevated scFv expression. Formation, size, and number of colonies were observed. Spots whose intensity was above 30 (arbitrary units) were considered as positive; ten such spots can be seen in the plate shown in Figure 3. This result indicates that positive clones expressing anti-human IgG scFvs were successfully identified using the scFv-PhoA library.

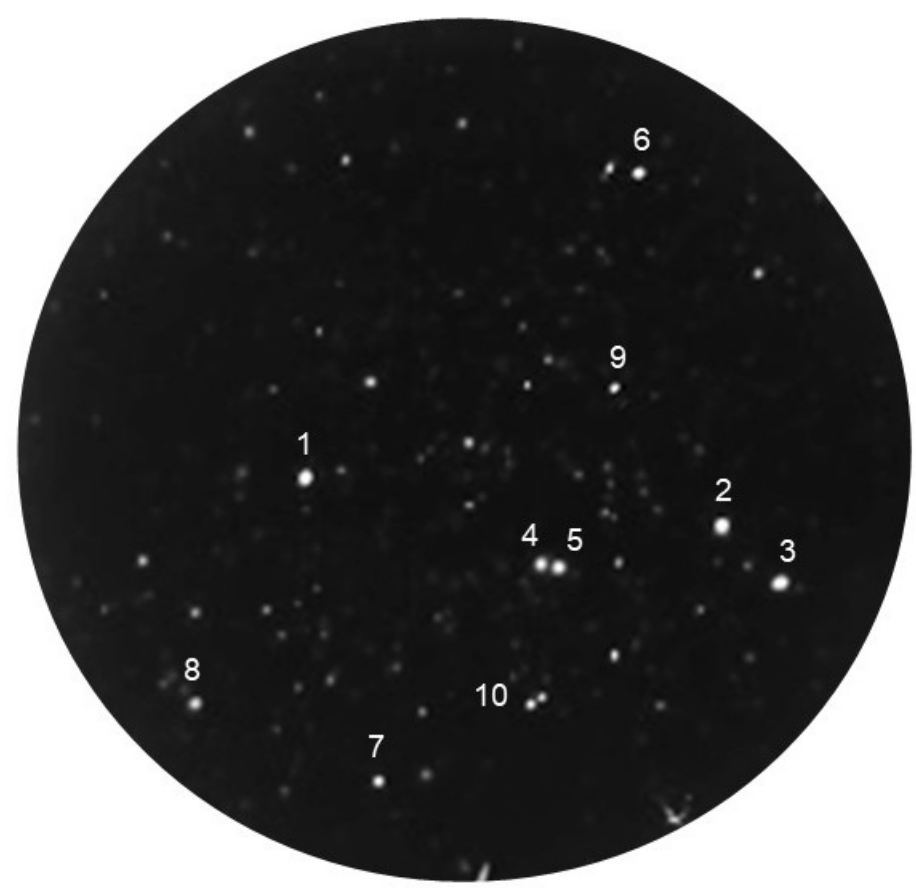

Figure 3. A representative nitrocellulose membrane showing positive clones from the scFv-PhoA library against human IgG. Antigen binding of scFvs to the membrane was detected by chemiluminescence. Seven positive spots that showed the strongest signal intensities were selected for further experiments.

Ten clones with the strongest signal and one exhibiting no signal were selected for further analysis. Each clone was identified by superimposing the filter on the membrane chemiluminescence image. Cells were picked from the upper filter and cultured to express scFvs. The selected positive and negative clones were cultured at $37^{\circ} \mathrm{C}$ in LB medium containing $50 \mu \mathrm{g} / \mathrm{mL}$ ampicillin until they reached OD600 of 0.6. Then, the cells were incubated at $30{ }^{\circ} \mathrm{C}$ for $6 \mathrm{~h}$ in the presence of $1 \mathrm{mM}$ isopropyl-D-1-thiogalactopyranoside (IPTG). Thereafter, they were centrifuged at $5000 \times g$ and $4{ }^{\circ} \mathrm{C}$ for $5 \mathrm{~min}$, and the supernatants were collected and readily examined for reactivity against human IgG using an enzyme-linked immunosorbent assay (ELISA) (Figure 4). Every identified positive clone showed antigen-specific binding activity. As a negative control, no binding was detected on the uncoated ELISA plate blocked with bovine serum albumin. Similarly, the negative clone did not bind to the antigen or bovine serum albumin. Thus, the colony assay with the scFv-PhoA library successfully established scFv-PhoA clones with binding affinity and specificity toward the antigen. 


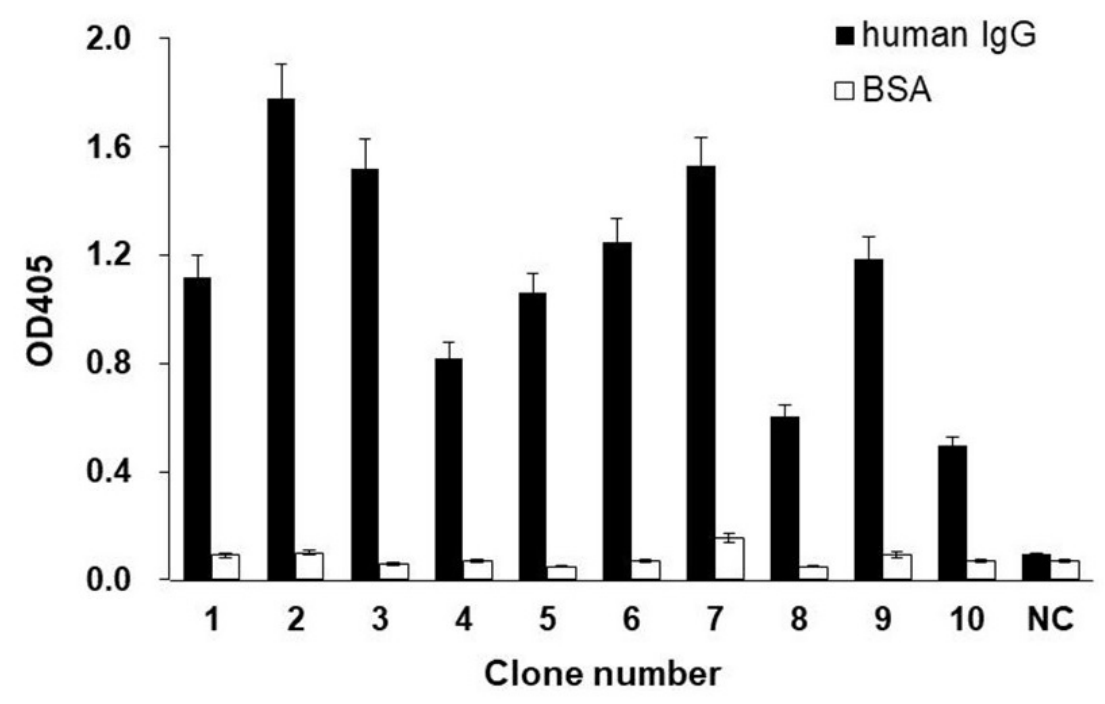

Figure 4. ELISA results showing the reactivity of culture supernatants from ten positive clones and one negative clone identified in Figure 3 against human IgG and bovine serum albumin (BSA; control). The negative clone (NC) was picked at random from colonies that showed no chemiluminescence signal. Data represent the mean of three replicates; error bars represent the standard deviation.

\subsection{Sequence Analysis of Selected Clones}

The DNA of each scFv from the ten clones (Figure 3) was sequenced. The inferred amino acid sequences of the ten clones are shown in Figure 5. Every clone contained the complete scFv structure consisting of heavy-chain variable domain $\left(\mathrm{V}_{\mathrm{H}}\right)$, linker, and light-chain variable domain $\left(\mathrm{V}_{\mathrm{L}}\right)$. All sequences were unique, indicating that diversity of the $\mathrm{scFv}$-PhoA library was maintained throughout the assay. These results show that genes encoding scFv-PhoA fusions with binding affinity for the antigen could be successfully isolated using our method.

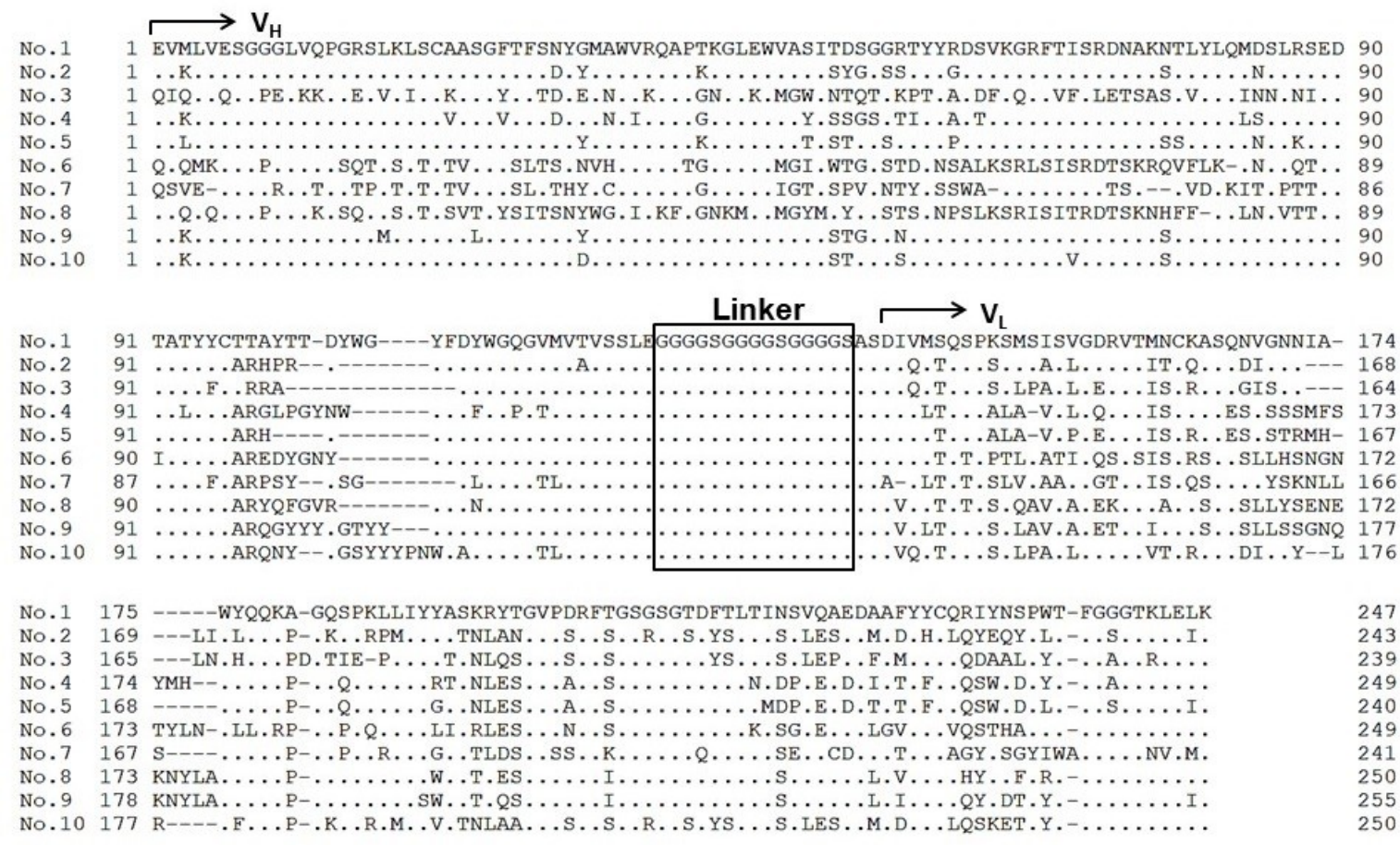

Figure 5. Amino acid sequence alignments of selected clones assayed. $\mathrm{V}_{\mathrm{L}}, \mathrm{V}_{\mathrm{H}}$, and linker sequences are shown. Dots and dashes indicate identical amino acids and deletions, respectively. 


\subsection{Comparison with the scFv Library}

The suitability of the scFv-PhoA screening method was tested with an anti-human IgG library. Anti-human IgG scFv and scFv-PhoA libraries were constructed and transformed into E. coli. Transformants were spread on 10 plates $\left(3 \times 10^{3}\right.$ bacteria per plate). To validate positive clones from the scFv-PhoA library, these were analyzed by colony PCR. Results from the colony assay performed with the two libraries were compared by counting the number of colonies on the filters and the spots corresponding to the positive clones on the antigen-coated membrane. As shown in Table 1, the number of colonies did not differ between the two methods, amounting to 12102 for $\mathrm{scFv}-\mathrm{PhoA}$ and 11083 for scFv. The ratios of positive colonies were also similar, $1.85 \%$ and $1.75 \%$, respectively. To validate the positive clones, these were analyzed by colony PCR and the size of the insert was checked by agarose gel electrophoresis. Positive clones with full-length scFv could be successfully obtained with both methods, and numbered 224 and 192 clones, respectively. All clones except two candidates from the scFv library presented full-length scFv inserts. The two incomplete clones were sequenced, revealing either absence of the $\mathrm{V}_{\mathrm{H}}$ fragments or a shorter linker. The ratio of positively identified clones was slightly higher with the $\mathrm{scFv}-\mathrm{PhoA}$ library than with the scFv library.

Table 1. Quantitative analysis of the colony-assay. E. coli were transformed with the scFv-PhoA and $\mathrm{scFv}$ libraries, and bacteria were spread on 10 plates $\left(3 \times 10^{3}\right.$ bacteria per plate). Colonies growing on the filter and spots corresponding to the positive clones on the antigen-coated membrane were counted. The number of colonies that had full-length scFv inserts was determined by colony PCR.

\begin{tabular}{ccccc}
\hline & $\begin{array}{c}\text { Number of } \\
\text { Colonies }\end{array}$ & $\begin{array}{c}\text { Number of } \\
\text { Positive Spots }\end{array}$ & Ratio (\%) & $\begin{array}{c}\text { Complete scFv } \\
\text { Insert }\end{array}$ \\
\hline scFv-PhoA library & 12,102 & 224 & 1.85 & 224 \\
scFv library & 11,083 & 194 & 1.75 & 192 \\
\hline
\end{tabular}

\section{Discussion}

The colony assay offers a superior approach for screening antibody libraries. It identifies clones by direct detection of antibody-antigen binding, thus resulting in a low false-positive rate [12,13]. Skerra et al. developed the filter-sandwich assay, in which colonies form directly on the hydrophilic filter and are then transferred to the antigen-coated membrane on the agar plate for scFv expression $[27,28]$. To save time, this assay omits the step whereby colonies are lifted from the agar plate to the nitrocellulose membrane. However, even like this, the procedure remains more complex than with other display methods and explains why the colony assay is not widely applied to screen antibody libraries. We previously developed a single-step colony assay that omitted the transfer of the colony filter prior to scFv expression [25]. This adjustment simplifies substantially the colony assay, reducing also contamination and cell death. To increase assay efficiency, we pioneered autoinduction of scFv expression during the assay [29]. ScFv expression represents a burden for E. coli growth and survival, and the induction reagent IPTG is toxic to the cells. As a result, strong induction of scFv expression occasionally leads to cell lysis and prevents rescue of the antibody gene from positive clones, decreasing overall screening efficiency. Owing to autoinduction, expression is induced at the optimal time and strength. While these improvements led to higher monoclonal antibody yields, the size of the antibody library that could be screened by this method was still much smaller than that used in phage-display $[8,30]$. To increase library size, here, the efficiency of the procedure was further improved by fusing scFv to the $\mathrm{N}$-terminus of alkaline phosphatase, yielding scFv-PhoA.

The dimerization of alkaline phosphatase in $\mathrm{scFv}$-PhoA clones has been shown to confer increased sensitivity over monomeric scFv [22]. PhoA ensures transport to the periplasmic space and the correct folding of scFv to form a disulfide bond. Fusion of scFvs to alkaline phosphatase provides a convenient, simple, and direct way of detecting antigen binding also in colony assays, substantially facilitating and speeding up the procedure [31,32]. Notably, detection of each membrane took only 10 min with 
$\mathrm{scFv}$-PhoA compared to $2 \mathrm{~h}$ with scFv. Monoclonal antibodies were successfully established with this method and the percentage of positive clones was almost identical to that obtained with scFv. Hence, the rapidity and simplicity of the proposed scFv-PhoA method will make it possible to scale-up the size of the library per assay and, consequently, increase the number of candidate positive clones.

The colony assay with scFv-PhoA has additional advantages over previous iterations. By omitting the need for a secondary antibody, background chemiluminescence is substantially reduced as the signal-to-noise ratio becomes higher. Coupled with increased sensitivity of detection due to scFv-PhoA dimerization, these adjustments substantially improve assay accuracy. Moreover, the improved signal allows mild induction of expression and higher rescue yield of positive clones. Here, we could use only $0.1 \%$ of lactose as inducer, instead of $0.15 \%$ for scFv. The success rate for establishing monoclonal scFvs was slightly better than that with the preceding method.

When producing $\mathrm{scFv}$ in E. coli, expression is strongly dependent on the scFv sequence [33,34]. This variability in expression prevents efficient screening as clones with low expression and high affinity against the antigen show a weak signal, whereas clones with high expression and low affinity show a strong signal. The sequence after the signal peptides and the following few amino acids are known to be important for expression and transport to the periplasm. Here, two amino acids from the $\mathrm{N}$-terminus of PhoA were used as the first two amino acids after the signal sequence [23]. Further fine-tuning could limit the observed variability in expression. Identification of optimal sequences could improve expression and colony formation in the colony assay and, consequently, increase library size per assay.

The colony assay using E. coli is simple and rapid owing to fast bacterial growth, thus allowing large libraries to be handled [35]. However, expression of some scFvs delays E. coli growth or leads to cell lysis [36,37]. In these cases, mutation or deletion of scFv genes is observed [38,39]. While this prevents cell death, it also reduces the yield of positive clones. In the colony assay, E. coli is exposed to inducers during detection and identification. With our method, the detection time was reduced to less than $1 / 10$, thus decreasing exposure to inducers and the risk of cell lysis. The higher sensitivity afforded by scFv-PhoA could further reduce the concentration of inducers. Still, a quantitative analysis deserves to be performed in future studies. The reduction of the library size was observed during our screening. When $3 \times 10^{4}$ clones were spread onto plates, we found only $1.2 \times 10^{4}$ colonies (Table 1 ). Some clones with toxic scFvs would not grow and form the colonies due to the leaky expression of these scFvs. These results suggest that a tighter expression regulation, including the suppression of scFvs leaky expression events, is required to prevent the library size reduction. Furthermore, the improvement of vectors and culture conditions is also necessary to maintain the library size. Any measure that lowers the stress on E. coli with $\mathrm{scFv}$ could have a positive effect on colony assay efficiency when screening antibody libraries.

A crucial advantage of the proposed colony assay is the possibility to observe antigen binding of $\mathrm{scFv}$ directly in real time. Accordingly, if we quantify the signal from positive clones, we may select those with the desired characteristics already during the assay. The size and magnitude of the signal may reflect the productivity and affinity of scFvs, respectively, which are key parameters for improving the assay.

In summary, use of the scFv-alkaline phosphatase fusion protein increased screening efficiency and yield of positive clones. With greater simplicity and speed of screening, it could be possible to enlarge the size of the library per assay. This, in turn, would increase the chance of obtaining positive clones with desired characteristics. Further improvements of the colony assay are required to handle the larger libraries.

\section{Materials and Methods}

\subsection{Immunization}

Approximately 6-week-old female Wister rats, obtained from SLC (Tokyo, Japan), were intraperitoneally (i.p.) injected with $100 \mu \mathrm{g}$ of normal human IgG, whole molecules, purified from 
serum (FUJIFILM Wako Pure Chemicals, Osaka, Japan), three times once every two weeks. The first injection was in complete Freund's adjuvant (Sigma-Aldrich, St. Louis, MO, USA), whereas the second and third were in incomplete Freund's adjuvant (Sigma-Aldrich) in a volume of $0.2 \mathrm{~mL}$. The rats were intravenously (i.v.) boosted with $100 \mu \mathrm{g}$ of human IgG in normal phosphate-buffered saline (PBS) one week after the third i.p. injection and then sacrificed three days after the i.v. boost, following which, their spleens were aseptically removed. All animals were cared for and maintained in accordance with the guidelines of the National Institute of Advanced Industrial Science and Technology (AIST). The project was approved by the committee for Experiments involving Animals of AIST (Project identification code: A2015-033, April 2015).

\subsection{Construction of scFv-PhoA and scFv Libraries}

RNA from the collected rat spleens was purified using the NucleoSpin RNA kit (Macherey-Nagel, Düren, Germany), and the corresponding cDNA was synthesized using the PrimeScript II Reverse Transcriptase 1st strand cDNA Synthesis Kit (Takara Bio, Shiga, Japan). cDNA was used as template for PCR amplification of $\mathrm{V}_{\mathrm{L}}$ and $\mathrm{V}_{\mathrm{H}}$ sequences; the amplification protocol was as follows: initial denaturation at $94^{\circ} \mathrm{C}$ for $2 \mathrm{~min} ; 25$ cycles of $98^{\circ} \mathrm{C}$ for $10 \mathrm{~s}, 56^{\circ} \mathrm{C}$ for $30 \mathrm{~s}$, and $68^{\circ} \mathrm{C}$ for $1 \mathrm{~min}$; and a final elongation step at $68^{\circ} \mathrm{C}$ for $2 \mathrm{~min}$. The PCR was performed using KOD FX polymerase (Toyobo, Osaka, Japan) with $10 \mathrm{pM}$ of the primers previously reported by Sepulveda and Shoemaker [40]. $\mathrm{NcoI}$ and XhoI restriction sites were added to the $5^{\prime}$ end of the forward and reverse $\mathrm{V}_{\mathrm{H}}$ primers, whereas NheI and NotI sites were added to the $5^{\prime}$ end of the forward and reverse $V_{L}$ primers, respectively. The pET-NXNN-PhoA (Figure 2) and pET-NXNN expression vectors were used for scFv-PhoA and scFv libraries, respectively. To construct pET-NXNN-PhoA, DNA fragments (Figure 2a) with signal peptide sequence (ssPhoA), linker, and restriction sites for cloning $\mathrm{V}_{\mathrm{H}}$ and $\mathrm{V}_{\mathrm{L}}$ fragments were synthesized by GenScript (Piscataway, NJ). The generated fragment was digested with NdeI and Bpu1102I (New England Biolabs, Ipswich, MA) and inserted into pET-NXNN (Figure 2b). Then, a mutated version of the bacterial alkaline phosphatase gene (phoA) [26] was inserted after the cloning site for scFvs by NotI and Bpu1102I. $\mathrm{V}_{\mathrm{L}}$ fragments and the vector were digested with NheI and NotI (New England Biolabs) and purified using the NucleoSpin Gel and PCR clean-up kit (Macherey-Nagel). The $\mathrm{V}_{\mathrm{L}}$ library was constructed by ligating $\mathrm{V}_{\mathrm{L}}$ fragments and the vector. Chemically competent $E$. coli DH5 $\alpha$ cells (Nippon Gene, Tokyo, Japan) were transformed with the resulting vectors. The transformed bacteria were incubated in $6 \mathrm{~mL} \mathrm{SOC}$ medium for $1 \mathrm{~h}$ at $37^{\circ} \mathrm{C}$, after which the cells were plated on LB plates supplemented with $1 \%$ glucose and $50 \mu \mathrm{g} / \mathrm{mL}$ ampicillin (FUJIFILM Wako Pure Chemicals) and cultured overnight at $37^{\circ} \mathrm{C}$. The cells were then collected, suspended in $10 \mathrm{~mL}$ LB medium, and the vectors containing the $\mathrm{V}_{\mathrm{L}}$ fragments were purified using the NucleoSpin Plasmid EasyPure kit (Macherey-Nagel). $V_{H}$ fragments and vectors containing the $\mathrm{V}_{\mathrm{L}}$ fragments were digested with $\mathrm{NcoI}$ and $\mathrm{XhoI}$ (New England Biolabs), and the scFv library was constructed by ligating the $\mathrm{V}_{\mathrm{H}}$ fragments to the vectors. E. coli BL21 (DE3) cells (Nippon Gene) were transformed with these vectors and cultured as described above. Then, the cells were collected and suspended in $10 \mathrm{~mL}$ LB medium supplemented with $50 \mu \mathrm{g} / \mathrm{mL}$ ampicillin and used for the colony assay.

\subsection{Colony Growth and scFv-PhoA and scFv Expression}

A nitrocellulose membrane of $9 \mathrm{~cm}$ in diameter (Bio-Rad Laboratories, Hercules, CA) was incubated for $2 \mathrm{~h}$ in PBS containing human IgG $(100 \mu \mathrm{g} / \mathrm{mL})$. The IgG-coated membrane was then blocked for $2 \mathrm{~h}$ in PBS containing 5\% nonfat dry milk, washed twice in PBS, and placed on a $10 \mathrm{~cm}$ LB agar plate containing $50 \mu \mathrm{g} / \mathrm{mL}$ ampicillin [29]. A hydrophilic PVDF filter of $9 \mathrm{~cm}$ in diameter (Durapore; Merck Millipore) was positioned atop the antigen-coated membrane. Transformed E. coli were grown in the above medium, and $1-5 \times 10^{3}$ cells from the exponential growth phase were suspended in LB medium containing $0.05 \%$ glucose and $0.1 \%$ lactose. In case of the scFv library, LB medium containing $0.05 \%$ glucose and $0.15 \%$ lactose was used. The suspension was spread on the filter and incubated at $30{ }^{\circ} \mathrm{C}$ for $24 \mathrm{~h}$. Colonies became visible after a $14 \mathrm{~h}$ incubation at $30{ }^{\circ} \mathrm{C}$, 
at which point $\mathrm{scFv}$-PhoA expression was induced automatically with lactose and glucose $[29,41]$. The expressed scFv-PhoA fusions diffused through the filter to the membrane, and those that exhibited binding affinity for the antigen were captured by the antigen immobilized on the membrane. The filter harboring the colonies was removed, placed in a fresh LB agar plate containing $1 \%$ glucose and $50 \mu \mathrm{g} / \mathrm{mL}$ ampicillin, and stored at $4{ }^{\circ} \mathrm{C}$ for later recovery of the bacteria. The nitrocellulose membrane was immersed in PBS containing 0.05\% Tween-20 (PBS-T) and used for the detection of antigen-specific scFv expression.

\subsection{Detection of Antigen Binding and Identification of Positive Clones}

The membrane obtained after the preceding step was washed twice. The chemiluminescence signal was detected using a Chemi-Stage CC16mini (KURABO, Osaka, Japan) after development with Novex AP chemiluminescent substrate (Thermo Fishes Scientific, Waltham, MA). For the scFv-library, the membrane was incubated for $2 \mathrm{~h}$ with a horseradish peroxidase (HRP)-conjugated anti-His antibody (1:5000 in PBS-T; FUJIFILM Wako Pure Chemicals), and then washed extensively in PBS-T. The chemiluminescence signal was detected using a Chemi-Stage CC16mini after development with a chemiluminescent HRP substrate kit (Immobilon Western; Merck Millipore). The filter harboring the colonies and the image presenting the chemiluminescence results were superimposed, allowing the positive colonies corresponding to the chemiluminescence signals to be identified.

\subsection{Expression of Positive Clones}

The selected positive clones were cultured at $37^{\circ} \mathrm{C}$ in LB medium containing $50 \mu \mathrm{g} / \mathrm{mL}$ ampicillin until they reached OD600 of 0.6. The cells were incubated at $30^{\circ} \mathrm{C}$ for $6 \mathrm{~h}$ in the presence of $1 \mathrm{mM}$ IPTG. They were centrifuged at $5000 \times g$ and $4{ }^{\circ} \mathrm{C}$ for $5 \mathrm{~min}$; the supernatants were collected and were analyzed using ELISA. All experiments were conducted twice, and the average signal intensity was used in the analysis.

\subsection{ELISA}

Each well of 96-well ELISA plates was coated with $100 \mu \mathrm{L}$ of $5 \mu \mathrm{g} / \mathrm{mL}$ human IgG, and then incubated with a blocking solution (Blocking Reagent for ELISA; Roche Diagnostics, Basel, Switzerland) for $2 \mathrm{~h}$. The plates were washed with PBS-T, after which $100 \mu \mathrm{L}$ of the supernatant of bacterial cultures was added to each well. The wells were washed. The amount of antigen-specific antibody present was measured using $p$-nitrophenyl phosphate (Sigma-Aldrich) and the plates were read using a microplate reader (Model 680; Bio-Rad Laboratories) at a wavelength of $405 \mathrm{~nm}$.

\subsection{Sequencing}

The expression vectors were purified from positive clones. The sequences of scFvs were determined on an ABI Perkin Elmer 373A automated DNA sequencer (Applied Biosystems, Foster City, CA, USA).

\subsection{Colony PCR of Positive Clones}

For statistical validation, colony PCR was performed on positive clones from each library [42]. Anti-human IgG scFv and scFv-PhoA libraries were constructed. E. coli were transformed with one of the two libraries, and bacteria were spread on 10 plates $\left(3 \times 10^{3}\right.$ bacteria per plate). The number of colonies and positive clones was counted for each library. Individual clones identified as positive for antigen binding were picked for colony PCR, which was carried out as follows: initial denaturation at $94{ }^{\circ} \mathrm{C}$ for $2 \mathrm{~min} ; 30$ cycles of $98{ }^{\circ} \mathrm{C}$ for $10 \mathrm{~s}, 63{ }^{\circ} \mathrm{C}$ for $15 \mathrm{~s}$, and $68{ }^{\circ} \mathrm{C}$ for $2 \mathrm{~min}$; and a final elongation step at $68{ }^{\circ} \mathrm{C}$ for $2 \mathrm{~min}$. The scFvs were amplified by PCR using Hot Start Taq DNA polymerase (Takara Bio) with forward (5'-CTGTGACAAAAGCCCGGACAG-3') and reverse primers (5'-CAGTAATATCGCCCTGAGC-3') at a concentration of $1 \mu \mathrm{M}$ each. The products were analyzed on a $1.5 \%$ agarose gel to check for size and purity. 


\section{Conclusions}

We report the development of a colony assay for screening antibody libraries using scFv fused to the $\mathrm{N}$-terminus of bacterial alkaline phosphatase ( $\mathrm{scFv}-\mathrm{PhoA})$ and a specifically designed expression vector. The colony assay was successfully carried out with the scFv-PhoA library inserted in this vector. Positive clones could be detected based on PhoA activity, without a secondary antibody. The detection procedure was simple and rapid. The monoclonal scFvs were established with a slightly better success rate than observed when using the scFv library, and the scFv-PhoA screening procedure was validated. High-throughput screening becomes possible with the scFv-PhoA library.

Author Contributions: Conceptualization, Y.H.; validation, Y.H. and M.K.; formal analysis, M.K.; investigation, M.K.; data curation, Y.H. and M.K.; writing—original draft preparation, Y.H.; writing—review and editing, Y.H.; project administration, Y.H. All authors have read and agreed to the published version of the manuscript.

Funding: This research received no external funding.

Conflicts of Interest: The authors declare no conflict of interest.

\section{References}

1. Weiner, G.J. Building better monoclonal antibody-based therapeutics. Nat. Rev. Cancer 2015, 15, 361-370. [CrossRef]

2. Reichert, J.M. Antibodies to watch in 2015. mAbs 2015, 7, 1-8. [CrossRef] [PubMed]

3. Schirrmann, T.; Meyer, T.; Schütte, M.; Frenzel, A.; Hust, M. Phage display for the generation of antibodies for proteome research, diagnostics and therapy. Molecules (Basel, Switzerland) 2011, 16, 412-426. [CrossRef] [PubMed]

4. Bradbury, A.; Sblattero, D. Exploiting recombination in single bacteria to make large phage antibody libraries. Nat. Biotechnol. 2000, 18, 75-80.

5. McCafferty, J.; Schofield, D. Identification of optimal protein binders through the use of large genetically encoded display libraries. Curr. Opin. Chem. Biol. 2015, 26, 16-24. [CrossRef] [PubMed]

6. Parmley, S.F.; Smith, G.P. Antibody-selectable filamentous fd phage vectors: Affinity purification of target genes. Gene 1988, 73, 305-318. [CrossRef]

7. Schofield, D.J.; Pope, A.R.; Clementel, V.; Buckell, J.; Chapple, S.D.; Clarke, K.F.; Conquer, J.S.; Crofts, A.M.; Crowther, S.R.E.; Dyson, M.R.; et al. Application of phage display to high throughput antibody generation and characterization. Genome Biol. 2007, 8, R254. [CrossRef]

8. Ledsgaard, L.; Kilstrup, M.; Karatt-Vellatt, A.; McCafferty, J.; Laustsen, A.H. Basics of antibody phage display technology. Toxins 2018, 10, 236. [CrossRef]

9. Matochko, W.L.; Cory Li, S.; Tang, S.K.Y.; Derda, R. Prospective identification of parasitic sequences in phage display screens. Nucleic Acids Res. 2014, 42, 1784-1798. [CrossRef]

10. de Wildt, R.M.; Mundy, C.R.; Gorick, B.D.; Tomlinson, I.M. Antibody arrays for high-throughput screening of antibody-antigen interactions. Nat. Biotechnol. 2000, 18, 989-994. [CrossRef]

11. Fitzgerald, V.; Leonard, P. Single cell screening approaches for antibody discovery. Methods 2017, 116, 34-42. [CrossRef] [PubMed]

12. Rauth, S.; Schlapschy, M.; Skerra, A. Selection of Antibody Fragments by Means of the Filter-sandwich Colony Screening Assay. In Antibody Engineering; Kontermann, R., Dübel, S., Eds.; Springer: Berlin/Heidelberg, Germany, 2010; pp. 255-266.

13. Kato, M.; Hanyu, Y. Colony Assay for Antibody Library Screening: Outlook and Comparison to Display Screening. In Antibody Engineering; Böldicke, T., Ed.; InTech: London, UK, 2018; pp. 1-17.

14. Chanussot, C.; Bellanger, L.; Ligny-Lemaire, C.; Seguin, P.; Ménez, A.; Boulain, J.C. Engineering of a recombinant colorimetric fusion protein for immunodiagnosis of insulin. J. Immunol. Methods 1996, 197, 39-49. [CrossRef]

15. Gillet, D.; Ezan, E.; Ducancel, F.; Gaillard, C.; Ardouin, T.; Istin, M.; Ménez, A.; Boulain, J.C.; Grognet, J.M. Enzyme Immunoassay Using a Rat Prolactin-Alkaline Phosphatase Recombinant Tracer. Anal. Chem. 1993, 65, 1779-1784. [CrossRef] [PubMed] 
16. Bettsworth, F.; Monnet, C.; Watelet, B.; Battail-Poirot, N.; Gilquin, B.; Jolivet, M.; Menez, A.; Arnaud, M.; Ducancel, F. Functional characterization of two anti-estradiol antibodies as deduced from modelling and site-directed mutagenesis experiments. J. Mol. Recognit. 2001, 14, 99-109. [CrossRef] [PubMed]

17. Muller, B.H.; Chevrier, D.; Boulain, J.C.; Guesdon, J.L. Recombinant single-chain Fv antibody fragment-alkaline phosphatase conjugate for one-step immunodetection in molecular hybridization. J. Immunol. Methods 1999, 227, 177-185. [CrossRef]

18. Ducancel, F.; Gillet, D.; Carrier, A.; Lajeunesse, E.; Ménez, A.; Boulain, J.C. Recombinant colorimetric antibodies: Construction and characterization of a bifunctional $\mathrm{F}(\mathrm{ab}) 2 /$ Alkaline phosphatase conjugate produced in Escherichia coli. Bio/Technology 1993, 11, 601-605. [CrossRef]

19. Carrier, A.; Ducancel, F.; Settiawan, N.B.; Cattolico, L.; Maillère, B.; Léonetti, M.; Drevet, P.; Ménez, A.; Boulain, J.C. Recombinant antibody-alkaline phosphatase conjugates for diagnosis of human IgGs: Application to anti-HBsAg detection. J. Immunol. Methods 1995, 181, 177-186. [CrossRef]

20. Mérienne, K.; Germain, N.; Zinn-Justin, S.; Boulain, J.C.; Ducancel, F.; Ménez, A. The functional architecture of an acetylcholine receptor-mimicking antibody. J. Biol. Chem. 1997, 272, 23775-23783. [CrossRef]

21. Griep, R.A.; Van Twisk, C.; Kerschbaumer, R.J.; Harper, K.; Torrance, L.; Himmler, G.; Van der Wolf, J.M.; Schots, A. pSKAP/S: An expression vector for the production of single-chain Fv alkaline phosphatase fusion proteins. Protein Expr. Purif. 1999, 16, 63-69. [CrossRef]

22. Martin, C.D.; Rojas, G.; Mitchell, J.N.; Vincent, K.J.; Wu, J.; McCafferty, J.; Schofield, D.J. A simple vector system to improve performance and utilisation of recombinant antibodies. BMC Biotechnol. 2006, 6, 46.

23. Boulain, J.C.; Ducancel, F. Expression of recombinant alkaline phosphatase conjugates in Escherichia coli. Methods Mol. Biol. (CliftonNj) 2004, 267, 101-112.

24. Dong, J.X.; Li, Z.F.; Lei, H.T.; Sun, Y.M.; Ducancel, F.; Xu, Z.L.; Boulain, J.C.; Yang, J.Y.; Shen, Y.D.; Wang, H. Development of a single-chain variable fragment-alkaline phosphatase fusion protein and a sensitive direct competitive chemiluminescent enzyme immunoassay for detection of ractopamine in pork. Anal. Chim. Acta 2012, 736, 85-91. [CrossRef] [PubMed]

25. Kato, M.; Hanyu, Y. Single-step colony assay for screening antibody libraries. J. Biotechnol. 2017, $255,1-8$. [CrossRef] [PubMed]

26. Muller, B.H.; Lamoure, C.; Le Du, M.-H.; Cattolico, L.; Lajeunesse, E.; Lemaître, F.; Pearson, A.; Ducancel, F.; Ménez, A.; Boulain, J.-C. Improving Escherichia coli Alkaline Phosphatase Efficacy by Additional Mutations inside and outside the Catalytic Pocket. ChemBioChem 2001, 2, 517-523. [CrossRef]

27. Skerra, A.; Dreher, M.L.; Winter, G. Filter screening of antibody Fab fragments secreted from individual bacterial colonies: Specific detection of antigen binding with a two-membrane system. Anal. Biochem. 1991, 196, 151-155. [CrossRef]

28. Dreher, M.L.; Gherardi, E.; Skerra, A.; Milstein, C. Colony assays for antibody fragments expressed in bacteria. J. Immunol. Methods 1991, 139, 197-205. [CrossRef]

29. Kato, M.; Hanyu, Y. Single-step colony assay with autoinduction of scFv expression for the screening of antibody libraries. BioTechniques 2019, 66, 194-197. [CrossRef]

30. Schaefer, J.V.; Honegger, A.; Plückthun, A. Construction of scFv Fragments from Hybridoma or Spleen Cells by PCR Assembly. In Antibody Engineering; Kontermann, R., Dübel, S., Eds.; Springer: Berlin/Heidelberg, Germany, 2010; pp. 21-44.

31. He, J.; Tao, X.; Wang, K.; Ding, G.; Li, J.; Li, Q.X.; Gee, S.J.; Hammock, B.D.; Xu, T. One-step immunoassay for the insecticide carbaryl using a chicken single-chain variable fragment (scFv) fused to alkaline phosphatase. Anal. Biochem. 2019, 572, 9-15. [CrossRef]

32. Xu, Z.L.; Dong, J.X.; Wang, H.; Li, Z.F.; Beier, R.C.; Jiang, Y.M.; Lei, H.T.; Shen, Y.D.; Yang, J.Y.; Sun, Y.M. Production and characterization of a single-chain variable fragment linked alkaline phosphatase fusion protein for detection of o,o-diethyl organophosphorus pesticides in a one-step enzyme-linked immunosorbent assay. J. Agric. Food Chem. 2012, 60, 5076-5083. [CrossRef]

33. Ayyar, B.V.; Arora, S.; Ravi, S.S. Optimizing antibody expression: The nuts and bolts. Methods 2017, 116, 51-62. [CrossRef]

34. Frenzel, A.; Hust, M.; Schirrmann, T. Expression of recombinant antibodies. Front. Immunol. 2013, 4, 217. [CrossRef] [PubMed]

35. Giovannoni, L.; Viti, F.; Zardi, L.; Neri, D. Isolation of anti-angiogenesis antibodies from a large combinatorial repertoire by colony filter screening. Nucleic Acids Res. 2001, 29, E27. [CrossRef] 
36. Hayhurst, A. Improved expression characteristics of single-chain Fv fragments when fused downstream of the Escherichia coli maltose-binding protein or upstream of a single immunoglobulin-constant domain. Protein Expr. Purif. 2000, 18, 1-10. [CrossRef] [PubMed]

37. Strachan, G.; Williams, S.; Moyle, S.P.; Harris, W.J.; Porter, A.J.R. Reduced toxicity of expression, in Escherichia coli, of antipollutant antibody fragments and their use as sensitive diagnostic molecules. J. Appl. Microbiol. 1999, 87, 410-417. [CrossRef] [PubMed]

38. Schirrmann, T.; Al-Halabi, L.; Dübel, S.; Hust, M. Production systems for recombinant antibodies. Front. Biosci. A J. Virtual Libr. 2008, 13, 4576-4594. [CrossRef]

39. Giacalone, M.J.; Gentile, A.M.; Lovitt, B.T.; Berkley, N.L.; Gunderson, C.W.; Surber, M.W. Toxic protein expression in Escherichia coli using a rhamnose-based tightly regulated and tunable promoter system. BioTechniques 2006, 40, 355-364. [CrossRef]

40. Sepulveda, J.; Shoemaker, C.B. Design and testing of PCR primers for the construction of scFv libraries representing the immunoglobulin repertoire of rats. J. Immunol. Methods 2008, 332, 92-102. [CrossRef]

41. Studier, F.W. Protein production by auto-induction in high-density shaking cultures. Protein Expr. Purif. 2005, 41, 207-234. [CrossRef]

42. Kato, M.; Hanyu, Y. Construction of an scFv library by enzymatic assembly of VL and VH genes. J. Immunol. Methods 2013, 396, 15-22. [CrossRef]

Sample Availability: Samples of the compounds are not available from the authors. 